\title{
Evaluation of blood and tooth element status in asthma cases: a preliminary case- control study
}

\author{
S. Songül Yalçın ${ }^{1^{*}}\left(\mathbb{0}\right.$, Nagehan Emiralioğlu' ${ }^{1}$ and Suzan Yalçın²]
}

\begin{abstract}
Background: Asthma is a common respiratory disorder; some data were present on the correlation between increased levels of some elements and the risk of asthma development. It was aimed to evaluate the levels of 13 selected blood and tooth elements (magnesium, phosphorus, calcium, chromium, manganese, iron, copper, zinc, strontium, molybdenum, cadmium, lead, mercury) in a well-controlled asthma group and the control group.
\end{abstract}

Methods: During the study period, 17 asthma patients and 26 age and gender-matched healthy children donated shed deciduous teeth having neither decay nor filling and enrolled for the study. The element levels in blood and teeth matrixes were analyzed with inductively coupled plasma mass spectrometry. Differences in blood and tooth elements in groups were evaluated with generalized linear models after adjusting confounding factors.

Results: After adjusting the child's "z scores of body mass index for age", history of iron deficiency anemia, and status of parental smoking, the generalized linear model revealed significantly lower tooth magnesium levels, lower blood zinc levels, and lower blood zinc/copper ratio in the asthma group than the control group $(p=0.042, p=0.034$, $p=0.002$, respectively). Other studied elements for tooth and blood matrixes were similar in groups.

Conclusion: Our study revealed some differences in tooth and blood element levels in the asthma group. Further studies on zinc and magnesium levels of severe asthma cases are necessary for the interpretation of the results.

Keywords: Asthma, Magnesium, Zinc, Mercury, Teeth, Blood

\section{Introduction}

Asthma is a common chronic respiratory disorder with airway inflammation, and the prevalence of asthma has increased in the last years. It is supposed that the increase in the prevalence of asthma is also related to the additional effects of environmental factors and lifestyle changes in addition to the genetic tendency [1-4]. Elements such as calcium $(\mathrm{Ca})$, phosphorus $(\mathrm{P})$, iron $(\mathrm{Fe})$, zinc $(\mathrm{Zn})$, magnesium $(\mathrm{Mg})$, copper $(\mathrm{Cu})$, cobalt $(\mathrm{Co})$, chromium $(\mathrm{Cr})$, manganese $(\mathrm{Mn})$, molybdenum (Mo),

\footnotetext{
*Correspondence: siyalcin@hacettepe.edu.tr; ssyalcin22@gmail.com

${ }^{1}$ Department of Pediatrics, Faculty of Medicine, Hacettepe University,

Ankara, Turkey
}

Full list of author information is available at the end of the article nickel (Ni) are important components for various biochemical and physiological functions of the human body. However, metals such as cadmium $(\mathrm{Cd})$, lead $(\mathrm{Pb})$, and mercury $(\mathrm{Hg})$ threaten human health $[2,3,5]$.

The main reason for asthma is a shift in the $\mathrm{T}$ helper 1 (Th1)/T helper 2 (Th2) balance towards a Th2 response leading to inflammation, and the risk of asthma development due to dysregulation of these metal homeostasis has been claimed recently $[1,2,5]$. This chronic inflammation in childhood asthma is triggered when the environmental factors lead to free oxidant radical production in genetically predisposed individuals. Furthermore, the concentration of these elements in serum may impact the antioxidant system, inflammation and airway 
hyper-responsiveness [6-8]. In studies using blood and urine samples, a cause-effect relationship cannot be established, only information about that moment can be obtained. Associations among cord blood, newborn hair, and breast milk were shown [9]. However, there is no study for interaction between maternal blood samples during the antenatal period and teeth samples of the child. Whereas, shed baby dental samples were analyzed in congenital heart diseases, obesity, and neurodevelopmental disorders to provide information about the prior element status, intrauterine, and infancy period [10-12]. After the development of baby teeth at the embryonic stage of the fetus, teeth eruption starts from 6 months after birth and shedding from 6 years of age [13]. Therefore, perinatal element status is important for teeth structure. Prenatal exposure to toxic metals like lead and manganese have been shown to be associated with adverse birth outcomes and this may affect the morbidity of these children although there is not enough research in this area $[14,15]$.

Interestingly, higher molar incisor hypomineralisation, a developmental enamel defect, was reported in asthma cases, previously $[16,17]$. Despite this, there was no published study in teeth element contents of asthma cases. Simultaneous investigation of blood and dental element levels can contribute to understanding the effect of these elements on the pathogenesis and prognosis of asthma. Here, we aimed to evaluate blood and deciduous tooth element levels $(\mathrm{Mg}, \mathrm{P}, \mathrm{Ca}, \mathrm{Cr}, \mathrm{Mn}, \mathrm{Fe}, \mathrm{Cu}, \mathrm{Zn}$, strontium $[\mathrm{Sr}], \mathrm{Mo}, \mathrm{Cd}, \mathrm{Pb}, \mathrm{Hg}$ ) in the bronchial asthma group and the control group. Elemental differences to be detected in dental samples will guide the explanation of the mechanism of the occurrence of asthma cases and will assist in the planning of new studies.

\section{Methods}

A case-control study was conducted at Hacettepe University Faculty of Medicine, between November 2016 and April 2017. Inclusion criteria consisted of cases with well-controlled asthma cases aged 6-12 years without coexistent malnutrition, and any other chronic disorders, and the presence of shed deciduous teeth within the last 3 days. Well-controlled asthma cases were not using any chronic inhaled or oral medication, and they had no symptoms and history of exacerbation within the previous year according to Global Initiative for Asthma (GINA) report [18]. There was no asthma history of their mothers. During the follow-up period, 17 asthma patients donated shed deciduous teeth having neither decay nor filling and enrolled for the study. Following each asthma case, one or two age- ( \pm 1 years) and gender-matched healthy children who gave shed deciduous teeth $(n=26)$ were recruited for the control group.
The local Ethical Committee approved the protocol. Parents gave verbal and written informed consent after receiving detailed explanations of the study.

Infant (gestational length, birth weight, age, gender of child, breastfeeding duration, vitamin/mineral supplements (yes or no), iron deficiency anemia history (yes or no), oral health (carious teeth and fillings on admission and history of tooth decay), current body weight and height of children), parental characteristics (age, education status, smoking history), and type of donated deciduous teeth (incisors or molar) were recorded in a structured questionnaire (Additional file 1).

The breastfeeding duration of a child was grouped as $\leq 12$ and $>12$ months. Parental education level was divided as $\leq 8$ and $>8$ years. The parental smoking status was classified as "both of them", "only one parent" and "none of them".

From each enrolled child, teeth were collected in plastic boxes. Venous blood sample (3-4 mL) was taken into 'metal-free' tubes containing ethylenediamine tetraacetic acid (BD Vacutainer ${ }^{\circledR}$ ) and divided into two parts. One part was studied for hemograms [hemoglobin $(\mathrm{Hb})$, mean corpuscular volume, red cell distribution width, platelets, white blood cell count]. The second part of blood and the teeth samples were stored at $+4^{\circ} \mathrm{C}$.

WHO AnthroPlus packet programme estimated " $\mathrm{z}$ " scores for height-for-age (HAZ), weight-for-age (WAZ), and body mass index (BAZ) [19].

Inductively coupled plasma mass spectrometry (Agilent Technologies 7700X Series, USA) detected element levels for $\mathrm{Fe}, \mathrm{Zn}, \mathrm{Ca}, \mathrm{Mg}$, P, $\mathrm{Sr}, \mathrm{Cu}, \mathrm{Mn}, \mathrm{Mo}, \mathrm{Cr}, \mathrm{Cd}, \mathrm{Pb}$, and $\mathrm{Hg}$ at Certificated Environment Laboratory. Analytic methods for blood and tooth samples and analytic quality control studies are similar to the previous study [10].

\section{Statistical analysis}

The Statistical Package for the Social Sciences (version 22.0, Chicago, IL, USA) performed statistical analyses. The Kolmogorov-Smirnov test and histograms determined the type of distribution. Normal distribution was present in some teeth elements $(\mathrm{Mg}, \mathrm{P}, \mathrm{Ca}$, and $\mathrm{Zn})$ and some blood elements ( $\mathrm{Mg}, \mathrm{P}, \mathrm{Fe}, \mathrm{Ca}, \mathrm{Cu}, \mathrm{Zn}, \mathrm{Sr}, \mathrm{Mo}, \mathrm{Cd}$ ). Others showed right-skewed distribution.

The differences between the asthma group and the control group were compared with an independent $t$-test in normally distributed parameters, and means and standard deviations (SD) were calculated. Mann-Whitney U test was used for the comparison of non-parametric subgroup analysis and quartiles were taken. Frequencies in categorical data were assessed by the Chi-square test and Fischer-exact test when necessary. When a difference was detected in the Chi-square test of the $3 \times 2$ table, adjusted residuals were calculated for subgroup differences. 
For each element level, the generalized linear model investigated differences between the asthma and the control groups. Factors having $p$ value less than 0.15 in univariate analysis (child's BAZ, history of iron deficiency anemia, and status of parental smoking) were taken as covariates. For elements with a normal distribution, identity was taken as the link function. "Gama with log link" was taken for scale response in elements showing rightskewed distribution. Estimated means and 95\% Confidence Interval (CI) of elements were calculated.

Statistical tests were two-sided, and statistical significance was at $p<0.05$.

\section{Results}

The study group consisted of 17 patients with asthma and 26 control cases without any chronic disease. The mean ages and the distribution of gender were similar in the groups (Table 1). The asthma group had a slightly higher BAZ value than the control group $(p=0.068)$. The asthma group and the control group were compared in terms of WAZ, HAZ, gestational length, and maternal age were found to be similar $(p>0.05)$.

There was no difference between the asthma group and the control group for breastfeeding more than 12 months, the presence of Fe prophylaxis, and vitamin

Table 1 Demographic characteristics of the study population

\begin{tabular}{|c|c|c|c|}
\hline & Control Group & Asthma Group & $p$ \\
\hline$n$ & 26 & 17 & \\
\hline \multicolumn{4}{|l|}{ Child characteristics } \\
\hline Age, years* & $7.8 \pm 1.7$ & $7.7 \pm 1.8$ & 0.885 \\
\hline Gender, Male, \%** & 53.8 & 52.9 & 0.954 \\
\hline Gestational length, week* & $39.1 \pm 2.1$ & $38.9 \pm 1.7$ & 0.737 \\
\hline Birth weight, gram* & $3283 \pm 687$ & $3129 \pm 383$ & 0.406 \\
\hline Breastfeeding $>12 \mathrm{mo} \% \%^{* *}$ & 80.8 & 87.5 & 0.690 \\
\hline Formula milk feeding, \%** & 32.0 & 23.5 & 0.731 \\
\hline Fe prophylaxis during infancy period, \%** & 57.7 & 47.1 & 0.494 \\
\hline Iron deficiency anemia history, \%** & 15.4 & 35.3 & 0.158 \\
\hline Vitamin prophylaxis during infancy period, $\%^{* *}$ & 34.6 & 41.2 & 0.663 \\
\hline Weight for age, z score & $0.17 \pm 0.82$ & $0.60 \pm 1.33$ & 0.275 \\
\hline Height for age, z score* & $0.45 \pm 0.93$ & $0.29 \pm 1.23$ & 0.628 \\
\hline Body mass index z score ${ }^{*}$ & $-0.11 \pm 0.95$ & $0.67 \pm 1.51$ & 0.068 \\
\hline History of tooth decay, \%** & 73.1 & 82.4 & 0.714 \\
\hline Presence of tooth decay or filling in mouth, \%** & 46.2 & 41.2 & 0.748 \\
\hline Studied tooth samples, incisors, \%** & 88.5 & 70.6 & 0.230 \\
\hline \multicolumn{4}{|l|}{ Hemograms } \\
\hline Hemoglobin, g/dL* & $12.8 \pm 1.0$ & $12.6 \pm 0.8$ & 0.661 \\
\hline Mean corpuscular volume, \%* & $80.5 \pm 5.5$ & $79.7 \pm 7.1$ & 0.666 \\
\hline Red cell distribution width, \%* & $13.7 \pm 0.8$ & $14.2 \pm 1.2$ & 0.150 \\
\hline White blood cell* $\mathrm{mm}^{3}$ & $8.3 \pm 2.6$ & $8.4 \pm 1.7$ & 0.975 \\
\hline Platelets* ${ }^{*} m^{3}$ & $304.5 \pm 75.6$ & $306.6 \pm 86.7$ & 0.933 \\
\hline \multicolumn{4}{|l|}{ Parental characteristics } \\
\hline Maternal age at the birth of index child, years ${ }^{*}$ & $26.9 \pm 6.6$ & $28.3 \pm 5.3$ & 0.460 \\
\hline Paternal age at the birth of index child, years ${ }^{*}$ & $30.9 \pm 5.6$ & $32.9 \pm 4.9$ & 0.229 \\
\hline Maternal education $>8$ years ${ }^{* *}$ & 65.4 & 64.7 & 0.964 \\
\hline Paternal education $>8$ years** & 75.0 & 68.8 & 0.728 \\
\hline Maternal occupation, presence ${ }^{* *}$ & 61.5 & 41.2 & 0.191 \\
\hline Parental smoking ${ }^{* *}$ & & & 0.008 \\
\hline None & 42.3 & $11.8^{\mathrm{a}}$ & \\
\hline Only one parent & 42.3 & $29.4^{\mathrm{a}}$ & \\
\hline Both of them & 15.4 & $58.8^{b}$ & \\
\hline
\end{tabular}

*Mean \pm SD; compared with independent t-test

**Data were compared with the Chi-square test and Fischer-exact test when appropriate

${ }^{\mathrm{ab}}$ Values having different letter were found to be statistically different, $p<0.05$ 
prophylaxis during the infancy period. No difference was present in the frequencies of studied incisor deciduous teeth in groups. The presence of tooth decay of filling in the mouth was $46.2 \%$ in the control group and $41.2 \%$ in the asthma group $(p=0.748)$. There was no difference in hemogram values in groups (Table 1 ).

The smoking of both parents was found to be more in the asthma group than those in the control group $(p=0.008$, Table 1$)$.

\section{Tooth and blood element levels}

Table 2 refers to the levels of elements in the tooth according to groups. The mean tooth $\mathrm{Mg}$ level was lower in the asthma group compared with the control group $(5.51 \pm 1.35 \mathrm{mg} / \mathrm{g}, 6.41 \pm 1.22 \mathrm{mg} / \mathrm{g}$; respectively, $p=0.030)$. On contrary, the mean blood $\mathrm{Mg}$ levels were similar among groups (Table 3). The teeth/blood ratio of $\mathrm{Mg}$ was lower in the asthma cases than the ratio in the control group $(13.6 \pm 4.6 \%, 16.6 \pm 4.5 \%$, respectively; $p=0.044)$.

Tooth Zn levels were similar in groups $(p=0.244$, Table 2). The mean blood $\mathrm{Zn}$ level was $5.04 \pm 1.06 \mathrm{mg} / \mathrm{L}$ in the asthma group and $5.86 \pm 1.16 \mathrm{mg} / \mathrm{L}$ in the control group, which was also detected to be statistically significant ( $p=0.026$, Table 3$)$. The blood $\mathrm{Zn} / \mathrm{Cu}$ ratio was also lower in the asthma cases than the ratio in the control group (4.54 $\pm 0.92,5.64 \pm 1.03$; respectively, $p=0.001$,
Table 2). The teeth/blood ratio of $\mathrm{Zn}$ was similar in the asthma cases and the control group $(22.4 \pm 4.6,21.4 \pm 6.8$, respectively; $p=0.592$ ).

No significant differences were detected in $\mathrm{P}, \mathrm{Ca}, \mathrm{Cr}$, $\mathrm{Mn}, \mathrm{Fe}, \mathrm{Cu}, \mathrm{Sr}, \mathrm{Mo}, \mathrm{Cd}, \mathrm{Pb}, \mathrm{Hg}$ levels in tooth and blood samples (Tables 2 and 3 ).

\section{Multivariate analysis}

When child's BAZ, history of iron deficiency anemia, and status of parental smoking were controlled, the generalized linear model detected lower tooth Mg levels in the asthma group compared to the control group (mean [95\% CI]: 5.46 [4.79-6.14], 6.44 [5.91-6.96] mg/g, respectively, $p=0.042)$. Asthma and the control group had similar teeth $\mathrm{P}$ levels and teeth $\mathrm{Mg} / \mathrm{P}$ ratios (Table 2).

After adjusting the child's BAZ, history of iron deficiency anemia, and status of parental smoking, the generalized linear model revealed significantly lower blood $\mathrm{Zn}$ levels and $\mathrm{Zn} / \mathrm{Cu}$ ratio in asthma cases than the control group (mean [95\% CI]: 4.99 [4.38-5.59], 5.89 [5.43-6.36] $\mathrm{mg} / \mathrm{L}$, respectively; $p=0.034$ for blood $\mathrm{Zn}$ levels and 4.50 [3.97-5.03], 5.66 [5.25-6.07], respectively; $p=0.002$ for $\mathrm{Zn} / \mathrm{Cu}$ ratio). However, blood $\mathrm{Cu}$ levels were similar in groups (Table 3).

Asthma cases had slightly lower tooth/blood ratio of $\mathrm{Mg}$ than the control group after controling for confounding factors (mean [95\% CI]: 13.5 [11.2-15.8], 16.6

Table 2 Concentration of elements within the tooth according to groups, in the asthma group and the control group

\begin{tabular}{|c|c|c|c|c|c|c|c|}
\hline & \multicolumn{4}{|c|}{ Univariate } & \multicolumn{3}{|l|}{ GLM $^{a}$} \\
\hline & Unit & $\begin{array}{l}\text { Control } \\
n=26\end{array}$ & $\begin{array}{l}\text { Asthma } \\
\mathrm{n}=17\end{array}$ & $p$ & $\begin{array}{l}\text { Control } \\
\mathbf{n}=26\end{array}$ & $\begin{array}{l}\text { Asthma } \\
\mathrm{n}=17\end{array}$ & $p$ \\
\hline $\mathrm{Mg}$ & $\mathrm{mg} / \mathrm{g}^{*}$ & $6.41 \pm 1.22$ & $5.51 \pm 1.35$ & 0.030 & $6.44[5.91-6.96]$ & $5.46[4.79-6.14]$ & 0.042 \\
\hline P & $\mathrm{mg} / \mathrm{g}^{*}$ & $139 \pm 20$ & $132 \pm 26$ & 0.378 & 139 [130-149] & 131 [119-143] & 0.332 \\
\hline $\mathrm{Mg} / \mathrm{P}$ & $\%$ ratio* & $4.66 \pm 0.94$ & $4.30 \pm 1.19$ & 0.283 & $4.67[4.24-5.10]$ & $4.29[3.73-4.85]$ & 0.336 \\
\hline $\mathrm{Ca}$ & $\mathrm{mg} / \mathrm{g}^{*}$ & $244 \pm 44$ & $229 \pm 56$ & 0.353 & 249 [229-269] & 222 [196-247] & 0.140 \\
\hline $\mathrm{Cr}$ & $\mu g / g^{* *}$ & $0.08(0.04 ; 0.18)$ & $0.07(0.05 ; 0.17)$ & 0.842 & $0.13[0.09-0.18]$ & $0.11[0.07-0.17]$ & 0.585 \\
\hline $\mathrm{Mn}$ & $\mu g / g^{* *}$ & $1.15(0.77 ; 1.72)$ & $1.09(0.47 ; 1.54)$ & 0.441 & 1.29 [1.01-1.64] & $1.04[0.76-1.41]$ & 0.305 \\
\hline $\mathrm{Fe}$ & $\mu \mathrm{g} / \mathrm{g}^{* *}$ & $5.56(3.88 ; 9.43)$ & $6.53(2.99 ; 8.64)$ & 0.785 & 8.26 [6.16-11.07] & $6.84[4.69-10.00]$ & 0.478 \\
\hline $\mathrm{Zn}$ & $\mu \mathrm{g} / \mathrm{g}^{*}$ & $120 \pm 27$ & $111 \pm 23$ & 0.244 & 120 [110-130] & $111[98-124]$ & 0.303 \\
\hline $\mathrm{Cu}$ & $\mu g / g^{* *}$ & $0.22(0.12 ; 0.45)$ & $0.30(0.16 ; 0.76)$ & 0.345 & $0.48[0.32-0.74]$ & $0.53[0.31-0.92]$ & 0.796 \\
\hline $\mathrm{Zn} / \mathrm{Cu}$ & Ratio** & $553(229 ; 1023)$ & $364(148 ; 714)$ & 0.285 & 786 [533-1160] & 413 [247-690] & 0.084 \\
\hline $\mathrm{Sr}$ & $\mu \mathrm{g} / \mathrm{g}^{* *}$ & $61(50 ; 104)$ & $73(50 ; 82)$ & 0.901 & 82 [66-103] & $91[68-122]$ & 0.613 \\
\hline Mo & $\mu g / g^{* *}$ & $0.02(0.02 ; 0.04)$ & $0.02(0.01 ; 0.05)$ & 0.901 & $0.04[0.02-0.05]$ & 0.05 [0.03-0.09] & 0.397 \\
\hline $\mathrm{Cd}$ & $\geq D L^{* * *}$ & $69.2 \%$ & $88.2 \%$ & 0.149 & & & \\
\hline $\mathrm{Pb}$ & $\mu g / g^{* *}$ & $0.59(0.50 ; 0.76)$ & $0.67(0.45 ; 0.91)$ & 0.619 & $0.70[0.59-0.83]$ & $0.68[0.55-0.85]$ & 0.889 \\
\hline $\mathrm{Hg}$ & $\geq \mathrm{DL}^{* * *}$ & $46.2 \%$ & $29.4 \%$ & 0.272 & & & \\
\hline
\end{tabular}

*Mean $\pm \mathrm{SD}$; compared with independent t-test

**Median (25; 75p); compared with Mann-Whitney U test

***\%; compared with the Chi-square test and Fischer-exact test when appropriate

a Estimated marginal mean [95\% Confidence Interval]; adjusted for child's BAZ, history of iron deficiency anemia, and status of parental smoking 
Table 3 Concentration of elements within the blood according to groups, in the asthma group and the control group

\begin{tabular}{|c|c|c|c|c|c|c|c|}
\hline & Univariat & & & & GLM $^{a}$ & & \\
\hline & Unit & $\begin{array}{l}\text { Control } \\
n=26\end{array}$ & $\begin{array}{l}\text { Asthma } \\
\mathrm{n}=17\end{array}$ & $p$ & $\begin{array}{l}\text { Control } \\
\mathbf{n}=26\end{array}$ & $\begin{array}{l}\text { Asthma } \\
\mathrm{n}=17\end{array}$ & $p$ \\
\hline $\mathrm{Mg}$ & $\mathrm{mg} / \mathrm{L}^{*}$ & $39.9 \pm 6.8$ & $41.7 \pm 5.7$ & 0.385 & $39.8[37.3-42.3]$ & $41.9[38.6-45.2]$ & 0.365 \\
\hline $\mathrm{P}$ & $\mathrm{mg} / \mathrm{L}^{*}$ & $402 \pm 69$ & $408 \pm 48$ & 0.786 & 399 [374-425] & 413 [379-446] & 0.570 \\
\hline $\mathrm{Mg} / \mathrm{P}$ & \%ratio** & $9.3(8.8 ; 11.8)$ & $10.0(8.7 ; 11.0)$ & 0.709 & 10.1 [9.4-10.9] & 10.3 [9.4-11.3] & 0.811 \\
\hline $\mathrm{Ca}$ & $\mathrm{mg} / \mathrm{L}^{*}$ & $64.8 \pm 7.5$ & $65.1 \pm 6.7$ & 0.894 & $65.0[62.1-68.0]$ & $64.8[61.0-68.6]$ & 0.936 \\
\hline $\mathrm{Cr}$ & $\mu g / L^{* *}$ & $0.81(0.76 ; 0.94)$ & $0.82(0.77 ; 0.95)$ & 0.535 & 0.85 [0.77-0.92] & 0.89 [0.79-0.99] & 0.575 \\
\hline $\mathrm{Mn}$ & $\mu g / L^{* *}$ & $9.6(8.3 ; 13.4)$ & $9.0(7.6 ; 11.2)$ & 0.214 & 10.7 [9.5-11.9] & 9.5 [8.2-11.0] & 0.272 \\
\hline $\mathrm{Fe}$ & $\mathrm{mg} / \mathrm{L}^{*}$ & $467 \pm 66$ & $467 \pm 44$ & 0.968 & 466 [444-488] & 468 [439-497] & 0.932 \\
\hline $\mathrm{Zn}$ & $\mathrm{mg} / \mathrm{L}^{*}$ & $5.86 \pm 1.16$ & $5.04 \pm 1.06$ & 0.026 & $5.89[5.43-6.36]$ & $4.99[4.38-5.59]$ & 0.034 \\
\hline $\mathrm{Cu}$ & $\mathrm{mg} / \mathrm{L}^{*}$ & $1.05 \pm 0.17$ & $1.13 \pm 0.19$ & 0.182 & $1.05[0.98-1.13]$ & $1.12[1.02-1.21]$ & 0.349 \\
\hline $\mathrm{Zn} / \mathrm{Cu}$ & Ratio* & $5.64 \pm 1.03$ & $4.54 \pm 0.92$ & 0.001 & $5.66[5.25-6.07]$ & $4.50[3.97-5.03]$ & 0.002 \\
\hline Sr & $\mu \mathrm{g} / \mathrm{L}^{*}$ & $18.6 \pm 5.8$ & $17.9 \pm 7.4$ & 0.757 & 17.2 [14.8-19.7] & 19.9 [16.7-23.1] & 0.237 \\
\hline Mo & $\mu g / L^{*}$ & $0.93 \pm 0.38$ & $0.86 \pm 0.33$ & 0.514 & $0.96[0.82-1.10]$ & $0.81[0.63-1.00]$ & 0.264 \\
\hline $\mathrm{Cd}$ & $\mu g / L^{* *}$ & $0.16(0.09 ; 0.23)$ & $0.15(0.12 ; 0.22)$ & 0.842 & $0.18[0.14-0.21]$ & $0.15[0.12-0.20]$ & 0.425 \\
\hline $\mathrm{Pb}$ & $\mu g / L^{* *}$ & $9.5(7.3 ; 12.5)$ & $9.9(8.5 ; 12.0)$ & 0.502 & $11.2[9.5-13.1]$ & $9.9[8.0-12.1]$ & 0.386 \\
\hline $\mathrm{Hg}$ & $\mu \mathrm{g} / \mathrm{L}^{* *}$ & $0.18(0.10 ; 0.36)$ & $0.20(0.15 ; 0.28)$ & 0.365 & $0.29[0.20-0.41]$ & $0.24[0.15-0.38]$ & 0.559 \\
\hline
\end{tabular}

${ }^{*}$ Mean \pm SD; compared with independent t-test

**Median (25; 75p); compared with Mann-Whitney U test

a Estimated marginal mean [95\% Confidence Interval]; adjusted for child's BAZ, history of iron deficiency anemia, and status of parental smoking

[14.9-15.8], respectively; $p=0.056)$. However, tooth/ blood Zn levels did not differ in asthma and control group (mean [95\% CI]: 21.2 [19.0-23.5], 22.7 [19.7-26.1], respectively; $p=0.480$ ).

\section{Discussion}

Some element levels from two biological samples, including blood $\mathrm{Zn}$ and tooth $\mathrm{Mg}$ were found to differ in asthma cases in our study.

The asthma group had significantly lower blood $\mathrm{Zn}$ values. Interestingly, a previous meta-analysis revealed that higher maternal $\mathrm{Zn}$ intake during the pregnancy period was associated with lower odds of wheeze during childhood [20]. In a recent study by Pan et al. it was concluded that $\mathrm{Zn}$ deficiency may be related to the IgE production and this relationship would increase the risk of asthma [21]. Dysregulation of $\mathrm{Zn}$ homeostasis was also proposed to reduce antioxidant functions and increase the risk of asthma development [22-24]. Despite this, the association between serum $\mathrm{Zn}$ levels and asthma pathogenesis remains controversial; some studies reported to have no significant association [2, 23-25], others showed low levels [22, 26, 27] or high levels [27]. Oeffelen et al. did not detect any association between serum $\mathrm{Zn}$ concentrations and childhood asthma in the PIAMA birth cohort study [25]. In the meantime, the serum $\mathrm{Zn}$ levels in the bronchial asthma group were found to be higher only in adult females than the control group; however, a positive correlation was reported between serum $\mathrm{Zn}$ levels and serum opsonic activity in both genders [27]. Differences might be explained by studied biologic samples, methods, age groups, and disease severity. Furthermore, a metaanalysis including twenty-six studies suggested that the asthma group had lower circulating Zn levels compared with the control groups [8]. Further studies with different biologic matrixes will clarify the situation.

Low Mg levels were seen in the tooth of asthma patients in this study. Low teeth $\mathrm{Mg}$ levels might propose the importance of perinatal $\mathrm{Mg}$ status in asthma pathogenesis, starting from the intrauterine period and infancy. As known, Mg causes the relaxation of bronchial smooth muscles. Reduced intake of $\mathrm{Mg}$ induces the worsening of pulmonary functions $[28,29]$. In addition, there was tooth hypomineralisation in asthma cases [17]. Interestingly, Liu et al. showed Mg could be an effective inducer of osteoblastic differentiation of stem cells from exfoliated deciduous teeth [30]. On the other hand, the blood Mg levels did not differ in asthma cases from our study. In addition, a meta-analysis of 34 studies showed that asthma cases had a lower level of $\mathrm{Mg}$ than the control group in the Asian population [2]. Alsharnoubi et al. also reported that $\mathrm{Mg}$ deficiency could lead to asthma development in children [31]. Another study reported a consistent inverse non-significant association between 
serum $\mathrm{Mg}$ levels and asthma prevalence in children at 8 years of age [25]. These differences could be due to the studied age of patients, disease severity, given medications, Mg homeostasis, studied biologic matrix such as blood, serum, teeth.

Blood and teeth $\mathrm{Hg}, \mathrm{Pb}$, and $\mathrm{Cd}$ levels were similar in the astma group and the control group in our study. This can be explained by cases having no known history of toxic metal contact in his or her family. Heinrich et al. found no differences in $\mathrm{Hg}$ levels in both blood and urine samples for asthma, wheezing, bronchial hyperresponsiveness, and allergic sensitization in children $(n=1056)$ aged 5-14 years from low exposure cases [32]. No influence of $\mathrm{Hg}$ levels on asthma was also stated in Korean adults [33] and a cross-sectional study with 5866 children aged 2-15 years from the NHANES survey 20072012 [34]. Similar to our study, Wells et al. reported similar blood $\mathrm{Pb}(1.13 \mu \mathrm{g} / \mathrm{dL})$ levels in a cross-sectional study of 1788 children and no association with asthma, atopic asthma, or general atopy, however, an increase in blood $\mathrm{Pb}$ [35] resulted in a significant increase in IgE and eosinophils $[11.1 \%$ (95\% CI 5.6, 16.9) and 4.9\% (2.3, 7.6) per $10 \mu \mathrm{g} / \mathrm{L} \mathrm{Pb}$. In addition, Rabito et al. showed no association between blood $\mathrm{Pb}$ levels of children aged 18-24 months and asthma diagnosis at 3 and 9 years of age [36]. On the other hand, inconsistent publications were also present. Wang et al. described a positive association for basal blood $\mathrm{Pb}$ with asthma in kindergarten children from Taiwan $(n=930)$. However, interaction with total serum IgE only in boys [37]. Wu et al. noted that cases with higher blood $\mathrm{Pb}$ levels had a higher odds for active asthma $(\mathrm{OR}=1.24)$, wheezing or whistling $(\mathrm{OR}=1.19)$ in the $6-11$ age group in a cross-sectional study [34]. No significant association in adult cases aged 20-79 years was reported between serum $\mathrm{Pb}$ with current wheeze or current asthma, regardless of smoking status [38]. Park et al. reported that the highest quintile of blood $\mathrm{Pb}$ revealed $67 \%$ higher odds for asthma compared to the lowest quintile in Korean adults [33]. Similarly, the most top quintile of blood Cd resulted in 55\% more risks than the lowest quintile [33]. Yang et al. reported a significant association for serum $\mathrm{Cd}$ with lower percentages of FEV1 and FEV1/FVC predicted in all adult participants and with current asthma in smokers [38]. On the other hand, environmental tobacco smoke is a common risk factor for exposure to numerous toxic substances and also wheezing and asthma in children [3, 4]. Given the higher frequency in asthma cases in our study, both maternal (slightly higher) and paternal smoke exposure (significantly higher) should be discussed in prenatal and perinatal developmental origins of childhood asthma.

No variations between the asthma group and healthy controls were detected in elements including $\mathrm{Ca}, \mathrm{Fe}, \mathrm{Cu}$,
$\mathrm{P}, \mathrm{Cr}, \mathrm{Mn}, \mathrm{Sr}$, and Mo levels in our study. A meta-analysis showed that asthma cases had markedly higher levels of $\mathrm{Cu}$ and $\mathrm{Fe}$ among overall populations and Asians [2]. A previous study also reported that the serum $\mathrm{Cu}$ concentrations in bronchial asthma patients tended to be higher compared with healthy individuals [24]. Higher levels of $\mathrm{Cu}$ and $\mathrm{Fe}$ may induce oxidative stress and chronic inflammation in asthma cases [2]. A study including controlled asthma, uncontrolled asthma, and control group investigated, $\mathrm{Cu}$ and $\mathrm{Pb}$ levels were increased in asthmatic groups and these levels were increased more obviously in moderate cases compared with the mild group [31]. Only one case-control study has investigated the role of $\mathrm{Mn}$ in asthma, and they concluded that Mn dietary intake is inversely related to bronchial hyperreactivity [24]. We have also measured the levels of $\mathrm{Mn}$ in both tooth and blood matrixes. Although the tooth and blood Mn levels were low in asthma patients, it was not statistically significant. Further studies with a large sample size could explain this relation.

Our results also showed that asthma cases had significantly higher parental smoke exposure and smoking history. This finding once again demonstrated to us the effect of smoke exposure on the pathogenesis of asthma as reported previously [39].

Some limitations were present in this study. The small sample size decreases the power of the study. Also, due to the cross-sectional design of this study, an accurate cause-effect relationship could not be formed. However, there are some strengths in the study. It is not easy to collect healthy deciduous teeth as a biological sample. Teeth samples may show perinatal exposure of children and could explain the pathogenesis of diseases [12]. This is the first study evaluating element levels in deciduous teeth from asthma cases. In addition, previous studies explored one or three elements in only one biological sample. However, in our study, several blood elements $(n=13)$ were analyzed in two separate biological materials at the same time. This study detecting the difference in the tooth sample will guide further studies evaluating asthma mechanisms.

\section{Conclusion}

Our study revealed low tooth $\mathrm{Mg}$ levels and low blood $\mathrm{Zn}$ levels in the asthma group. Further studies on the zinc and magnesium levels of asthma at different severity levels will contribute to the interpretation of the results of the current study. $\mathrm{Mg}$ and $\mathrm{Zn}$ status could be evaluated in future studies in the management of asthma cases. Our study will shed light on other studies about the management of asthma cases. Further studies are necessary to show the relationship between asthma and elements for 
understanding asthma development and the prevention of disease.

\section{Supplementary Information}

The online version contains supplementary material available at https://doi. org/10.1186/s12890-021-01565-9.

Additional file 1. Data collection form

\section{Acknowledgements}

The authors are grateful to families donating deciduous teeth. We are grateful to Yahya Laleli for their valuable technical advice at Duzen Laboratories GroupResearch and Development Department.

\section{Authors' contributions}

SSY contributed to the conceptualization and design of the study, the data collection, and revised the manuscript. SY contributed to the conceptualization and design of the study, performed the statistical analyses and revised the manuscript. NE drafted the initial manuscript, and reviewed the final manuscript. All authors approved the final manuscript as submitted and agree to be accountable for all aspects of this work.

\section{Funding}

This study was partially supported by The Scientific and Technological Research Council of Turkey-TUBITAK SBAG-214S282.

\section{Data sharing}

Research data can be requested from the corresponding author.

\section{Declarations}

\section{Ethics approva}

All procedures performed in studies involving human participants were in accordance with the ethical standards of the institutional and/or national research committee and with the 1964 Helsinki declaration and its later amendments or comparable ethical standards. Hacettepe University, Faculty of Medicine Institutional Review Board approved the protocol.

\section{Informed consent}

Informed consent was obtained from parents included in the study.

\section{Competing interest}

The authors declare that they have no conflicts of interest. The funding organization[s] played no role in the study design; in the collection, analysis, and interpretation of data; in the writing of the report; or in the decision to submit the report for publication.

\section{Author details}

${ }^{1}$ Department of Pediatrics, Faculty of Medicine, Hacettepe University, Ankara Turkey. ${ }^{2}$ Department of Food Hygiene and Technology, Faculty of Veterinary Medicine, Selçuk University, Konya, Turkey.

Received: 1 April 2021 Accepted: 4 June 2021

Published online: 15 June 2021

\section{References}

1. Anandan C, Nurmatov U, van Schayck OC, Sheikh A. Is the prevalence of asthma declining? Systematic review of epidemiological studies. Allergy. 2010;65(2):152-67.

2. Mao S, Wu L, Shi W. Association between trace elements levels and asthma susceptibility. Respir Med. 2018;145:110-9.

3. Yang SN, Hsieh CC, Kuo HF, Lee MS, Huang MY, Kuo CH, Hung CH. The effects of environmental toxins on allergic inflammation. Allergy Asthma Immunol Res. 2014;6(6):478-84.
4. Murrison LB, Brandt EB, Myers JB, Hershey GKK. Environmental exposures and mechanisms in allergy and asthma development. J Clin Invest. 2019;129(4):1504-15.

5. Tchounwou PB, Yedjou CG, Patlolla AK, Sutton DJ. Heavy metal toxicity and the environment. Exp Suppl. 2012;101:133-64.

6. Jesenak M, Zelieskova M, Babusikova E. Oxidative stress and bronchial asthma in children-causes or consequences? Front Pediatr. 2017;5:162.

7. Kuti BP, Kuti DK, Smith OS. Serum zinc, selenium and total antioxidant contents of Nigerian children with asthma: association with disease severity and symptoms control. J Trop Pediatr. 2020;66(4):395-402.

8. Chen M, Sun Y, Wu Y. Lower circulating zinc and selenium levels are associated with an increased risk of asthma: evidence from a meta-analysis. Public Health Nutr. 2020;23(9):1555-62.

9. Dursun A, Yurdakok K, Yalcin SS, Tekinalp G, Aykut O, Orhan G, Morgil GK. Maternal risk factors associated with lead, mercury and cadmium levels in umbilical cord blood, breast milk and newborn hair. J Matern Fetal Neonatal Med. 2016;29(6):954-61.

10. Yalcin SS, Firat MC, Tosun E, Yalcin S. A possible etiological factor in obesity: element status in blood and tooth of overweight versus normalweight children. Int J Environ Health Res. 2018;29:1-13.

11. Yalçın SS, ÇakT, Yalçın S. Lower strontium in two different body matrices in neurodevelopmental disorders: a preliminary report. J Trace Elem Med Biol. 2020;62:126553.

12. Yalçin SS, Dönmez Y, Aypar E, Yalçin S. Element profiles in blood and teeth samples of children with congenital heart diseases in comparison with healthy ones. J Trace Elem Med Biol. 2021;63:126662.

13. Markman L. Teething: facts and fiction. Pediatr Rev. 2009;30(8):e59-64

14. Zhu M, Fitzgerald EF, Gelberg KH, Lin S, Druschel CM. Maternal low-level lead exposure and fetal growth. Environ Health Perspect. 2010;118(10):1471-5.

15. Cassidy-Bushrow AE, Sitarik AR, Havstad S, Park SK, Bielak LF, Austin C, Johnson CC, Arora M. Burden of higher lead exposure in AfricanAmericans starts in utero and persists into childhood. Environ Int. 2017;108:221-7.

16. Flexeder C, Kabary Hassan L, Standl M, Schulz H, Kuhnisch J. Is There an Association between Asthma and Dental Caries and Molar Incisor Hypomineralisation? Caries Res. 2020;54(1):87-95.

17. Silva MJ, Scurrah KJ, Craig JM, Manton DJ, Kilpatrick N. Etiology of molar incisor hypomineralization - a systematic review. Community Dent Oral Epidemiol. 2016;44(4):342-53.

18. Global Initiative for Asthma. Pocket guide for asthma management and prevention. 2021. https://ginasthma.org/.

19. World Health Organization. WHO AnthroPlus for personal computers manual: software for assessing growth of the world's children and adolescents. Geneva: WHO; 2009.

20. Beckhaus AA, Garcia-Marcos L, Forno E, Pacheco-Gonzalez RM, Celedon JC, Castro-Rodriguez JA. Maternal nutrition during pregnancy and risk of asthma, wheeze, and atopic diseases during childhood: a systematic review and meta-analysis. Allergy. 2015;70(12):1588-604.

21. Pan Z, Zhang X, Hui Y, Xiang H, Wang Q, Xu S, Li L. Sex difference between trace elements and pulmonary functions in children. Biol Trace Elem Res. 2020;197(2):405-10.

22. Guo CH, Liu PJ, Hsia S, Chuang CJ, Chen PC. Role of certain trace minerals in oxidative stress, inflammation, CD4/CD8 lymphocyte ratios and lung function in asthmatic patients. Ann Clin Biochem. 2011;48(Pt 4):344-51.

23. Picado C, Deulofeu R, Lleonart R, Agusti M, Mullol J, Quinto L, Torra M. Dietary micronutrients/antioxidants and their relationship with bronchial asthma severity. Allergy. 2001;56(1):43-9.

24. Kocyigit A, Armutcu F, Gurel A, Ermis B. Alterations in plasma essential trace elements selenium, manganese, zinc, copper, and iron concentrations and the possible role of these elements on oxidative status in patients with childhood asthma. Biol Trace Elem Res. 2004;97(1):31-41.

25. van Oeffelen AA, Bekkers MB, Smit HA, Kerkhof M, Koppelman GH, Haveman-Nies A, van der AD, Jansen EH, Wijga AH. Serum micronutrient concentrations and childhood asthma: the PIAMA birth cohort study. Pediatr Allergy Immunol. 2011;22(8):784-93.

26. Ariaee N, Farid R, Shabestari F, Shabestari M, Jabbari Azad F. Trace elements status in sera of patients with allergic asthma. Rep Biochem Mol Biol. 2016;5(1):20-5.

27. Urushidate S, Matsuzaka M, Okubo N, Iwasaki H, Hasebe T, Tsuya R, Iwane K, Inoue R, Yamai K, Danjo K, et al. Association between concentration of 
trace elements in serum and bronchial asthma among Japanese general population. J Trace Elem Med Biol. 2010;24(4):236-42.

28. Chitamanni P, Chandrasekaran V, Rajendiran S. Serum total magnesium level and its correlation with symptom control in children with mild persistent asthma. Indian J Pediatr. 2018;85(6):420-5.

29. Schuh S, Sweeney J, Freedman SB, Coates AL, Johnson DW, Thompson G, Gravel J, Ducharme FM, Zemek R, Plint AC, et al. Magnesium nebulization utilization in management of pediatric asthma (MagNUM PA) trial: study protocol for a randomized controlled trial. Trials. 2016;17(1):261. https:// doi.org/10.1186/s13063-015-1151-x.

30. Liu YJ, Su WT, Chen PH. Magnesium and zinc borate enhance osteoblastic differentiation of stem cells from human exfoliated deciduous teeth in vitro. J Biomater Appl. 2018;32(6):765-74.

31. Alsharnoubi J, Alkharbotly A, Waheed H, Elkhayat Z, Hussein DY. Could we diagnose childhood asthma by LIBS technique? Lasers Med Sci. 2020;35(4):807-12.

32. Heinrich J, Guo F, Trepka MJ. Brief report: low-level mercury exposure and risk of asthma in school-age children. Epidemiology. 2017;28(1):116-8.

33. Park S, Lee EH, Kho Y. The association of asthma, total IgE, and blood lead and cadmium levels. J Allergy Clin Immunol. 2016;138(6):1701-3.e6. https://doi.org/10.1016/j.jaci.2016.04.030.

34. Wu KG, Chang CY, Yen CY, Lai CC. Associations between environmental heavy metal exposure and childhood asthma: a population-based study. J Microbiol Immunol Infect. 2019;52(2):352-62.
35. Wells EM, Bonfield TL, Dearborn DG, Jackson LW. The relationship of blood lead with immunoglobulin E, eosinophils, and asthma among children: NHANES 2005-2006. Int J Hyg Environ Health. 2014;217(2-3):196-204.

36. Rabito FA, Horter L, Langlois EC, Carlson JC, White LE, Schwartz K, Osman P, Rice JC. Blood lead and pediatric asthma. Epidemiology. 2013;24(3):474-6

37. Wang IJ, Karmaus WJJ, Yang CC. Lead exposure, IgE, and the risk of asthma in children. J Expo Sci Environ Epidemiol. 2017;27(5):478-83.

38. Yang G, Sun T, Han YY, Rosser F, Forno E, Chen W, Celedon JC. Serum cadmium and lead, current wheeze, and lung function in a nationwide study of adults in the united states. J Allergy Clin Immunol Pract. 2019;7(8):2653-60.e3. https://doi.org/10.1016/j.jaip.2019.05.029.

39. Peden DB. The "envirome" and what the practitioner needs to know about it. Ann Allergy Asthma Immunol. 2019;123(6):542-9.

\section{Publisher's Note}

Springer Nature remains neutral with regard to jurisdictional claims in published maps and institutional affiliations.
Ready to submit your research? Choose BMC and benefit from:

- fast, convenient online submission

- thorough peer review by experienced researchers in your field

- rapid publication on acceptance

- support for research data, including large and complex data types

- gold Open Access which fosters wider collaboration and increased citations

- maximum visibility for your research: over 100M website views per year

At BMC, research is always in progress.

Learn more biomedcentral.com/submissions 